\title{
Bent vagyunk a vízben, avagy a magyar balneológia tudományos eredményei az ezredfordulótól napjainkig
}

\author{
Bender Tamás dr. \\ Budai Irgalmasrendi Kórház, Budapest
}

Bár a közlemény az elmúlt 20 év balneológiai tudományát tárgyalja, de erról a kérdésről nem lehet anélkül írni, hogy a XIX-XX. század kiemelkedő magyar orvos egyéniségeit ne említsük, hiszen abban a korban olyan híres magyar orvosok foglalkoztak balneológiával (és vettek részt aktívan a balneológiai egyesület életében), mint a hazai nógyógyászat megalapítója, Tauffer Vilmos, egyben a Magyar Balneológiai Egyesület (MBE) alapító elnöke, Hőgyes Endre, Markusovszky Lajos, Dalmady Zoltán (a hazai sportorvoslás úttörője), Korányi Sándor (máig is a világon az egyik leghíresebb belgyógyászunk) vagy Bókay Árpád, a későbbiekben pedig Schulhof Ödön, de Châtel Andor, Moll Károly, Belák Sándor (a magyar tudományos reumatológia megalapítója). Bár a múlt században történt, de mérföldkőnek számított a Bálint Géza vezette munkacsoport munkája, mely a világon először közölt angol nyelven, kettős vakmódszerrel végzett balneológiai vizsgálatot térdarthrosisos betegeken 1989-ben [1]. Az ezredfordulóig kevés magyar balneológiai közlemény jelent meg angol nyelven: ennek oka részint, hogy a II. világháború után a tudományág visszaszorult hazánkban, részint az angol nyelvü orvosi adatbázisok is csak az 1970-es évektől teljesedtek ki, részint a szakmának alig volt tudományos elismertsége itthon. Az elmúlt 20 évben összességében (de ez a szám folyamatosan növekszik!) 30 balneológiai tárgyú közlemény jelent meg angol nyelven, impaktfaktoros lapokban (ezek eredeti közlemények!), fóleg a mozgásszervi betegségek témaköréből például $[2,3]$, de jelentek meg bőrgyógyászati [4] és nőgyógyászati [5], valamint kardiológiai tárgyú publikációk is [6], emellett számos kísérletes munka $[7,8]$, összefoglaló közlemény [9], szerkesztői levél [10]. A külföldön publikált cikkek mellett magyar orvosi újságokban is jelentek meg tudományos közlemények. Tekintettel arra a tényre, hogy a magyar ásványvizek gyógyvízzé nyilvánításához egy klinikai tanulmány elkészítése szükséges, e vizsgálatok felét kettős vakmódszerrel végezték, melyek döntő többsége meg- maradt jegyzőkönyvi szinten: ennek oka, hogy a szerzők vagy nem kívánták közölni a tanulmányt, de leginkább, hogy a munka nem érte el a közléshez szükséges tudományos kritériumrendszert. Így is 20 közlemény jelent meg a mozgásszervi betegségek tárgyköréből, ebből 6 kettős vak-, 6 pedig kontrollált utánkövetéses módszerrel készült. Ha a magyar szerzők külföldi lapokban publikált vizsgálatait diagnózis szerint elemezzük, akkor a legtöbb vizsgálatban a következők szerepeltek: térdarthrosis, például Cserkeszőlő [2], Nagybaracska [11]; elvétve csípőarthrosis, például Mezőkövesd [12]; kézarthrosis, például Gunaras [13]; gyakran krónikus derékfájás, például Celldömölk vagy Mátraderecske [14, 15]. Ha víz összetételét nézzük, akkor nagyon kevert és változatos képet kapunk. Térdarthrosis esetén vizsgálat történt például hévízi kalcium-magnézium-hidrogén-karbonátos, kénes vízzel [16], nagybaracskai nátrium-kalciumhidrogén-karbonátos, kloridos, jodidos termálvízzel [11], derékfájás esetén a celldömölki nátrium-bikarbonátos [14] és a mátraderecskei magas sótartalmú vízzel is [15]. A bőrgyógyászati és a nőgyógyászati javallattal végzett vizsgálatok száma elenyészô a többihez képes, ilyen vizsgálatok a harkányi kénes vízzel, illetve a parádi timsós vízzel készültek $[4,5]$. A gyógyvizek mellett ötfajta gyógyiszappal (kolopi, hévízi, marosi és neydhartingi , tiszasülyi) történt orvosi kontrollált vizsgálat arthrosisban, melyek közül 3 kettős vakvizsgálat, 1 egyszeres vak-, 1 pedig randomizált kontrollált vizsgálat volt. Ezekból 3 külföldi impaktfaktoros lapban jelent meg [17-19]. A fürdők mellékhatásai nagyon kis számban fordultak elő (például kénallergia kénes fürdőnél, fertőzések elvétve stb.), ugyanakkor megjegyzendő, hogy 2014-ben a magyar cikkek metaanalízisét (ez is kuriózumnak számít a világban) publikáló tanulmány 1199 beteg közül mindössze 7\%-os kiesési arányról számolt be [9]. Ha az okokat nézzük, hogy mi vezetett a balneológiai közleményeknek az elmúlt 20 évben történt ilyen ugrásszerű növekedéséhez, akkor elsőként említhetjük 
azt a tényt, hogy a nemzetközi termálszervezetek közül a leginkább orvosi jellegúnek számító International Society of Medical Hydrology and Climatology (ISMH) 2002 és 2008 között, második alkalommal, magyar elnököt és pénztárost választott (eddig egy évig 1929-ben báró Korányi Sándor volt magyar elnök). A 2000-es évek elején az Új Széchenyi Terv és a kutatások támogatása világított rá a magyar balneológiára (sajnos ez 2005 óta megszúnt - de ez egy másik történet); annyit azért érdemes megjegyezni, hogy Franciaországban az Association Française pour la Recherche Thermale (AFRETH) biztosítja a tudományos vizsgálatok hátterét. Ez a nonprofit szervezet minden évben 1,2 millió euróval támogatja a kutatást. A Francia Orvosi Akadémia külön termálosztállyal is rendelkezik. Olaszországban a gyógyvizek tudományos kutatásával foglalkozó alapítvány (Fondazione per la Ricerca Scientifica Termale - FORST) 2003 és 2011 között összesen közel 5 millió eurót ítélt oda kutatási tevékenységekre. Nálunk a sok ígéret ellenére sajnos elmaradt a balneológiai kutatások támogatása. 2011-ben magyar kezdeményezésre az Európai Unió orvosi szakbizottsága (Union Européenne des Médecins Spécialistes - UEMS) Physical and Rehabilitation Medicine (PRM) szekciójának keretén belül megalakult egy balneológiai munkacsoport, magyar elnökkel. A Szegedi Tudományegyetem (SZTE) és a Pécsi Tudományegyetem (PTE) Általános Orvostudományi Karán Doktori Iskola jött létre, melynek keretén belül számos balneológia tárgyú doktori értekezés született. Szegeden inkább a balneológia klinikuma volt a téma, most lesz az 5 . védés ebben a témakörben, míg Pécsett az experimentális jellegû́ vizsgálatok dominálnak inkább. Számos országgal rendezett a Magyar Balneológiai Egyesület bilaterális szimpóziumot, ezenkívül több, nemzetközi kooperációban készült közlemény jelent meg magyar szerzőkkel $[20,21]$, és van olyan is, amelynek már több százas az idézettsége [22] - ez ebben a tudományágban kiugrónak számít. Európai reumatológiai és rehabilitációs kongresszusokon egyre több balneológiai témájú előadás hangzik el magyar előadók részvételével. A SZTE-n és a PTE-n a medikusok számára a balneológia választható, kreditpontos tantárgy lett. 2011-tôl a Balneológia helyet kapott a szakmai kollégium tagozatai között. Ma Magyarország a világ négy, legtöbbet publikáló országainak egyike (angol nyelven) Franciaország, Olaszország és Törökország mellett. Meg kell említeni, hogy az orosz közleményeknek csak az absztraktjuk jelenik meg angolul (így ezeket nem vettük számításba, mivel a teljes cikk nem áll rendelkezésre angol nyelven). Alig jelenik meg a világban balneológiai tárgyú közlemény, amelynek irodalmi hivatkozásában nincs magyar idézettség. A kezdeti nehézségek után már nemcsak a reumatológiai vagy rehabilitációs lapok közölnek elvétve balneológiai tárgyú közleményeket, hanem például az International Journal of Biometeorology (IF: 2,68) nyújtott lehetőséget balneológiai közleményekre, köztük sok magyar szerzőnek, és a balneológiai közleményekre való tekintettel magyar or- vos is bekerült a folyóirat tanácsadó testületébe (Advisory Board). Ha a környező országok nemzetközi publikációit nézzük, a hasonló termálforrásszámmal rendelkező Románia alig publikált angol nyelvú balneológiai cikket, hasonlóan keveset közölt Csehország és Szlovákia, míg Németországban és Ausztriában lényegesen csökkent az elmúlt évtizedekben a publikációk száma. Az angolszász és a skandináv országok termálforrások hiányában nem érdekeltek a balneológiában, de például az Egyesült Államokban pár éve alakult balneológiai egyesület, és a távol-keleti országokból (Dél-Korea, Kína) is növekvő számú balneológiai közlemény jelenik meg. Igen érdekes, hogy a világ legtöbb termálforrásával rendelkező és évezredes tradicionális fürdőkultúrájú Japán tudományos érdeklődése inkább a szív- és keringési betegségek balneológiai kutatását részesíti elónyben. Izrael a Holt-tenger miatt a mozgásszervi betegségek mellett a bőrgyógyászati és a klimatológiai tudományos kutatást favorizálja. Ha a fenti eredményeket nézzük, más klinikai szakmákhoz képest nyilván nagyon kevés a közlemények száma, ám ha az előző évtizedek balneológiai publikációihoz hasonlítjuk ôket, akkor kiemelkedően sok. Magyarország - és ezt számos helyen olvashatjuk a sajtóban - gyógyvíznagyhatalomnak számít, de ezen nemcsak a termálforrások számát, hanem inkább a természetes gyógytényezők (leginkább gyógyvizek) klinikai alkalmazását értjük. A mozgásszervi betegségeken kívül számos szakmában használhatjuk termálvizeinket krónikus betegségek kiegészítő kezeléseként. A balneoterápia nem csodaszer, de speciális lehetőség az orvosi szakma kezében, melyet a gyógyszerek mellett a betegek kezelésében tudunk alkalmazni. Az ország jelentős részében rendelkezésre állnak gyógyvizek, és a kezelések nagy részét a Nemzeti Egészségbiztosítási Alapkezelő (NEAK) támogatja; jól megválasztott indikáció esetén a gyógyvíznek alig van mellékhatása, olcsó, és már számos tudományos bizonyíték áll rendelkezésünkre a hatását illetően [23]. Még nagyon sok kiaknázatlan lehetőség van a balneoterápia klinikai használatában, például termálvizes inhaláció (orr-fül-gégészeti, pulmonológiai betegek számára), gyógyvizes ivókúra (gyomor-bél rendszeri betegek számára), szabad szénsavgáz (mofetta) érbetegségben szenvedők kezelésére. Az eddig elért tudományos eredményeket nem túlbecsülvén, de a fent említett tények és evidenciák talán jók arra, hogy ez az évtizedek óta kissé tudománytalannak minősített szakma több figyelmet és elismerést kapjon.

\section{Irodalom}

[1] Szúcs L, Ratkó I, Leskó T, et al. Double-blind trial on the effectiveness of the Püspökladány thermal water on arthrosis of the knee-joints. J R Soc Health 1989; 109: 7-9.

[2] Kovács I, Bender T. The therapeutic effects of Cserkeszőlő thermal water in osteoarthritis of the knee: a double blind, controlled, follow-up study. Rheumatol Int. 2002; 21: 218-221.

[3] Tefner IK, Kovács Cs, Gaál R, et al. The effect of balneotherapy on chronic shoulder pain. A randomized, controlled, single- 
blind follow-up trial. A pilot study. Clin Rheumatol. 2015; 34: 1097-1108.

[4] Péter I, Jagicza A, Ajtay Z, et al. Balneotherapy in psoriasis rehabilitation. In Vivo 2017; 31: 1163-1168.

[5] Zámbó L, Dékány M, Bender T. The efficacy of alum-containing ferrous thermal water in the management of chronic inflammatory gynaecological disorders. A randomized controlled study. Eur J Obstet Gynecol Reprod Biol. 2008; 140: 252-257.

[6] Németh B, Kiss I, Jencsik T, et al. Angiotensin-converting enzyme inhibition improves the effectiveness of transcutaneous carbon dioxide treatment. In Vivo 2017; 31: 425-428.

[7] Tékus V, Borbély É, Kiss T, et al. Investigation of Lake Hévíz mineral water balneotherapy and Hévíz mud treatment in murine osteoarthritis and rheumatoid arthritis models. Evid Based Complement Alternat Med. 2018; 2018: 4816905.

[8] Gerencsér G, Szabó I, Szendi K, et al. Effects of medicinal waters on the UV-sensitivity of human keratinocytes. A comparative pilot study. Int J Biometeorol. 2019; 63: 1417-1423.

[9] Bender T, Bálint G, Prohászka Z, et al. Evidence-based hydroand balneotherapy in Hungary. A systematic review and metaanalysis. Int J Biometeorol. 2014; 58: 311-323.

[10] Varga C. On the proper study design applicable to experimental balneology. Int J Biometeorol. 2016; 60: 1307-1309.

[11] Bálint GP, Buchanan WW, Ádám A, et al. The effect of the thermal mineral water of Nagybaracska on patients with knee joint osteoarthritis. A double blind study. Clin Rheumatol. 2007; 26: 890-894.

[12] Kovács Cs, Bozsik Á, Pecze M, et al. Effects of sulfur bath on hip osteoarthritis: a randomized, controlled, single-blind, follow-up trial: a pilot study. Int J Biometeorol. 2016; 60: 1675-1680.

[13] Horváth K, Kulisch A, Németh A, et al. Evaluation of the effect of balneotherapy in patients with osteoarthritis of the hands: a randomized controlled single-blind follow-up study. Clin Rehabil. 2012; 26: 431-441

[14] Kulisch A, Bender T, Németh A, et al. Effect of thermal water and adjunctive electrotherapy on chronic low back pain: a double-blind, randomized, follow-up study. J Rehabil Med. 2009; 41: 73-79.
[15] Tefner IK, Németh A, Lászlófi A, et al. The effect of spa therapy in chronic low back pain: a randomized controlled, single-blind, follow-up study. Rheumatol Int. 2012; 32: 3163-3169.

[16] Kulisch Á, Benkő Á, Bergmann A, et al. Evaluation of the effect of Lake Hévíz thermal mineral water in patients with osteoarthritis of the knee: a randomized, controlled, single-blind, follow-up study. Eur J Phys Rehabil Med. 2014; 50: 373-381.

[17] Tefner IK, Gaál R, Koroknai A, et al. The effect of Neydharting mud-pack therapy on knee osteoarthritis: a randomized, controlled, double-blind follow-up pilot study. Rheumatol Int. 2013; 33: 2569-2576

[18] Gyarmati N, Kulisch A, Németh A, et al. Evaluation of the effect of Hévíz mud in patients with hand osteoarthritis: a randomized, controlled, single-blind follow-up study. Isr Med Assoc J. 2017; 19: 177-182.

[19] Király M, Kővári E, Hodosi K, et al. The effects of Tiszasüly and Kolop mud pack therapy on knee osteoarthritis: a double-blind, randomised, non-inferiority controlled study. Int J Biometeorol. 2020; 64: 943-950.

[20] Fioravanti A, Karagülle M, Bender T, et al. Balneotherapy in osteoarthritis: facts, fiction and gaps in knowledge. Eur J Integrative Med. 2017; 9: 148-150.

[21] Gutenbrunner C, Bender T, Cantista P, et al. A proposal for a worldwide definition of health resort medicine, balneology, medical hydrology and climatology. Int J Biometeorol. 2010; 54: 495-507.

[22] Bender T, Karagülle Z, Bálint GP, et al. Hydrotherapy, balneotherapy, and spa treatment in pain management. Rheumatol Int. 2005; 25: 220-224.

[23] Bender T. Based on the recent evidence for what kind of diseases are the Hungarian thermal water beneficial? [Milyen betegségekre jók a magyar gyógyvizek a rendelkezésünkre álló bizonyítékok alapján?] Lege Artis Med. 2017; 27: 86-92. [Hungarian]

(Bender Tamás dr., Budapest, Árpád fejedelem útja 7., 1023 e-mail: bender.tamas@t-online.hu) 